\title{
Heat transfer enhancement with nanofluids: A review of recent applications and experiments
}

\author{
Izza A. Ismail*, Mohd Z. Yusoff, Firas B. Ismail, Prem Gunnasegaran \\ Department of Mechanical Engineering, Universiti Tenaga Nasional, Kajang 43000, Malaysia
}

Corresponding Author Email: izzaadillah@gmail.com

https://doi.org/10.18280/ijht.360426

Received: 19 August 2017

Accepted: 24 October 2018

\section{Keywords:}

nanofluid, thermal conductivity, applications of nanofluids, heat transfer enhancement

\begin{abstract}
Since the 1990's, nanofluids have been one of the abundantly preferred newcomer technology invented to assist in electronic and heat transfer purposes. Their thermophysical properties and heat transfer performance make nanofluids highly demanded to overcome the current issues in the world. In this paper, a vast number of applications using nanofluids are reviewed as well as an epitome on the challenges in their respective areas. Additionally, recent research papers for specific applications of nanofluids in improving heat transfer efficiency were outlined while the experimental and theoretical methods were discussed in the articles and journals is summarized in this paper including the effects of thermal properties on the performance of nanofluids. In a nutshell, this review of experimental research extracted from most recent papers, published from 2011 to 2016, is a review on the latest updates in the nanofluids and heat transfer community to help anyone in concern of the topic and enough information to select nanofluids based on their needed applications.
\end{abstract}

\section{INTRODUCTION}

Conventional fluids, such as deionized (DI) water or ethylene glycol (EG), used as the common working fluids in heat transfer applications have inherently low thermal conductivity relative to metals as well as metal oxides. Therefore, solid particles $(\mathrm{Np})$ are added to these fluids to enhance their thermal conductivity. The product of this suspension is called a nanofluid, a term proposed by Choi in 1995 of the Argonne National Laboratory, U.S.A. [1].

Figure 1 is a representative graph of the emerging growth of publications written by the nanofluids and heat transfer community produced by Gianluca Puliti et al. [2] for the research papers published between years 1992-2010. Based on the graph presented, the numbers of papers published in the total of 8 years have increased from less than 100 in 2004 to a total of more than 1200 in 2010. Experimental and analytical researches were done in various papers such as $M$. Sheikholeslami et al. [3-5] and A. Tohidi et al. [6] published a 2015 and 2016 paper on a mathematical research on the heat transfer properties of nanofluid in certain applications.

Figure 2 shows the number of papers mentioned in this review according to its year published. In this paper we present an overview of the literature dealing with the recent evolution of the nanofluid community.

Nanofluids are suspensions of metallic or non-metallic nanopowders of sizes less than $100 \mathrm{~nm}$ in a base liquid. Modern nanotechnology provides new opportunities to process and produce materials with average crystallite sizes below $50 \mathrm{~nm}$ [2]. Several types of $n p$ have been used for enhancing thermal conductivity including copper oxide, titanium dioxide, alumina trioxide, silver, diamond, etc.

Based on previous studies, it can be summarized that decreasing the size of $\mathrm{np}$ enhances the thermal conductivity incredibly. Aside from that, increasing the volume fraction percentage of nanoparticle against base fluid will increase the thermal conductivity. However, the addition of macro and microsized particles excessively can create problems like agglomeration and sedimentation. Hence, several experiments that have been performed contain no more than $2.0 \mathrm{vol} \%$ of nanoparticle added to the base fluid.

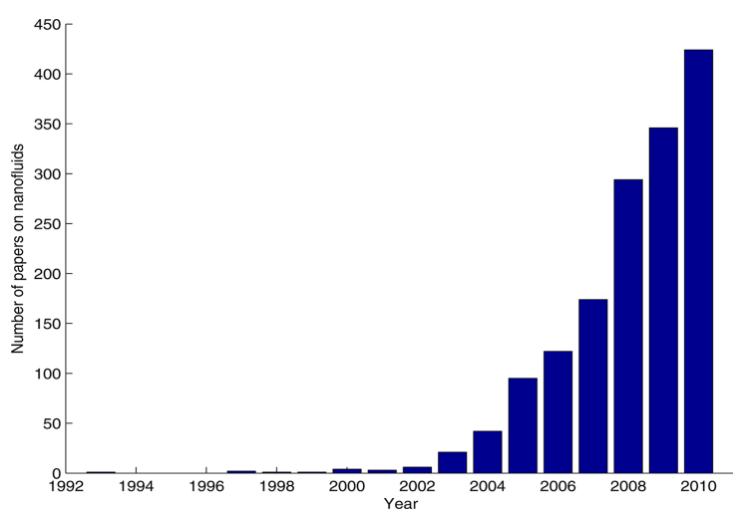

Figure 1. Growth of publications on nanofluids

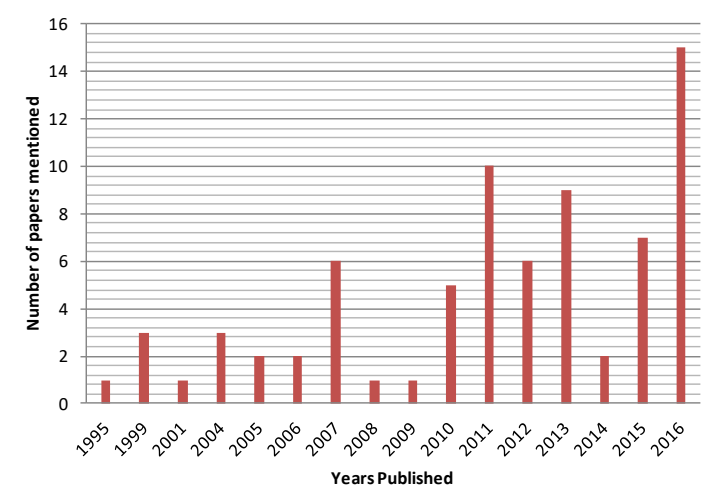

Figure 2. Published papers mentioned 
In this paper, several experimental studies are discussed as their rig set up and purposes are highlighted. Papers published in the set of 6 years, from 2011 to 2017 , were researched and compared briefly on the design and applications. Experimental set ups differing from using natural convection, fibre glass, to changing the number and positions of thermocouples have affected their outcome and the use of nanofluid as a heat transfer medium is the main core of all the researches discussed. As we approach an era of optimization and enhancement of properties, nanofluid researchers will have a summary in this review paper as grounds to build their research around.

\section{OVERVIEW OF APPLICATIONS OF NANOFLUIDS}

Most nanofluids are applied in technologies where the efficiency of the product is highly dependable on the heat transfer efficiency and enhancing it with the least cost, space, and material is considered a big achievement in the industry. An increase in any of these factors, i.e. h, surface area, and temperature difference will increase the heat flow in the system. As the $\Delta \mathrm{T}$ and $\mathrm{h}$ are often limited due to the working condition and the used material, many technologies nowadays are aiming to increase the heat transfer area in order of maximizing the heat flow; for example, hybrid cars [7-8].

\subsection{Heat exchangers}

The application of nanofluids in heat exchanger industry includes plate heat exchangers, shell and tube heat exchangers, compact heat exchangers, and double pipe heat exchangers [9]. In a general view, Kaufui V. et al. [10] presented an article explaining the role of nanofluids in industries of heat transfer, automotive, electronic, and biomedical applications. Several published papers [10-18] were involved in heat transfer industries such as industrial cooling applications, smart fluids, nuclear reactors, and extraction of geothermal power and other energy sources respectively.

\subsection{Automotive}

Nanofluids in the automotive industry are widely discussed by heat transfer researchers in the past; many of which have experimented nanofluids with the efficiency of heat transfer via the coolant and engine fuel. Both applications rely on the high-thermal conductivity of nanofluids. The cooling and low friction properties of nanofluids also introduced them to applications in automotive through brakes and lubrication [10]. Some papers on nanofluids [19-20] talk about heat transfer enhancements to use in automotive applications.

\subsection{Electronics}

Current technologies use microchips which require an efficient cooling system. Based on H. B. Ma et al. [21], in combination with thin film evaporation, the nanofluid oscillating heat pipe (OHP) cooling system will be able to remove heat fluxes over $10 \mathrm{MW} / \mathrm{m}^{2}$ and serve as the next generation cooling devices that will be able to handle the heat dissipation coming from new technologies. Other papers [14$15,22-23$ ] discuss shortly the contribution of their nanofluid researches in the electronic industry.

\subsection{Biomedical}

Nanodrug Delivery, Cancer Therapeutics, Cryopreservation, Nanocryosurgery, and Sensing \& Imaging are five of the most common applications of nanofluid in the biomedical industry [24]. Kaufui V. et al. [10] stated that there is a new initiative which takes advantage of several properties of certain nanofluids to use in cancer imaging and drug delivery. Magnetic nanofluids are to be used to guide the particles up the bloodstream to a tumor with magnets and allow doctors to deliver high local doses of drugs or radiation without damaging nearby healthy tissue.

\subsection{Nuclear}

As one of the major industries where heat transfer is required as one of its main processes, the nuclear industry is also one of the major applications of nanofluid. The cooling of nuclear reactor cores is an important stage of nuclear reacting and nanofluids have played a role in the process. In a study done by Hadad et al. [13] investigated the thermal hydraulic attribution of $\mathrm{Al}_{2} \mathrm{O}_{3}$ /water nanofluid as coolant in a VVER1000 nuclear reactor core by using a CFD code based on finite volume method for single-phase and two-phase mixture models to find $\mathrm{h}$ and pressure drop. In a study by S. J. Kim et al. [12], nanofluids are used as the main reactor coolant for pressurized water reactors (PWRs). It could enable significant power uprates in current and future PWRs, thus enhancing their economic performance with at least $32 \%$ higher critical heat flux (CHF) and a $20 \%$ power density uprate in current plants without changing the fuel assembly design and without reducing the margin to $\mathrm{CHF}$.

\section{RESEARCH METHOD ANALYSIS}

\subsection{Nanofluid preparation}

Throughout the evolution of nanofluids used for enhancing heat transfer efficiency, many types of material, metal and non-metal alike, were used. The most common nanoparticle materials used for nanofluid preparation are alumina and copper. Recently after 2015 alone, there have been more than 125 highly cited research papers investigating alumina nanofluids solely for heat transfer purposes. To name a few papers by Rashid Purrajab et al., G. Srinivas Rao et al., Heydar Maddah et al, and Vijaya Kumar et al. [25-27, 17] could be mentioned. Veeranna Sridhara et al. [28] have profusely summarized on the many experiments done by various researchers in the nanofluids community which uses alumina, alumina trioxide, and alumina oxide etc.

Eastman JA, S. Lee, MS Liu, Jana S [29-31], and many more have done experiments on copper np and copper oxide in both water and ethylene glycol base fluid. Most experiments in previous papers have used nanofluid or nanoparticle purchased from by chemical companies.

Few of the researchers have produced their own nanofluids via several methods [31-23]. Generally, there are two fundamental methods to produce nanofluids; the single-step direct evaporation method and the two-step method. Singlestep method consists of the direct evaporation and condensation of the nanoparticle materials in the base liquid to produce stable nanofluids. In the latter, the $n p$ is obtained by different methods first and then are dispersed into the base 
liquid $[17,28]$. In a review by X. Q. Wang et al. [32], the twostep method is extensively used in the synthesis of nanofluids considering the available commercial nanopowders supplied by several companies. In this method, np were first produced and then dispersed the base fluids. Generally, ultrasonic equipment is used to intensively disperse the particles and reduce the agglomeration of particles.

After preparation, several steps are to be taken before they are able to be experimented for its heat transfer properties. Tests that should be carried out are such as characterization and functionalization. Methods for both of these tests include using x-ray diffractometry, FTIR, TGA, TEM, and Raman spectroscopy. Details differ according to material. For example, in the paper written by Ahmad Amiri et al. [23], functionalization of hydrogen exfoliated graphene (HEG) is done by synthesizing HEG with concentrated H2SO4:HNO3 with ratio of 3:1 whereas in a research done by Yan Deng et al [22], graphene sheets were functionalized with presynthesized polymer via a combination of atom transfer nitroxide radical coupling chemistry with the grafting-onto strategy.

Stabilization is also an important part in preparing the nanofluid used for the industry as it will render biphasic heat transfer. In an excerpt taken from a study on the $\mathrm{h}$ of $\mathrm{CuO}$ in water by M. Naraki et al. [33], nanofluid used has been stabilized with variations of $\mathrm{pH}$ and using Sodium Dodecyl Sulfonate (SDS) surfactant. Figure 3 shows an example photo of nanofluids before and after stabilization [23]. After the processes have been done, the nanofluid obtained is used in experimental set ups testing the properties and other matters [34-38].

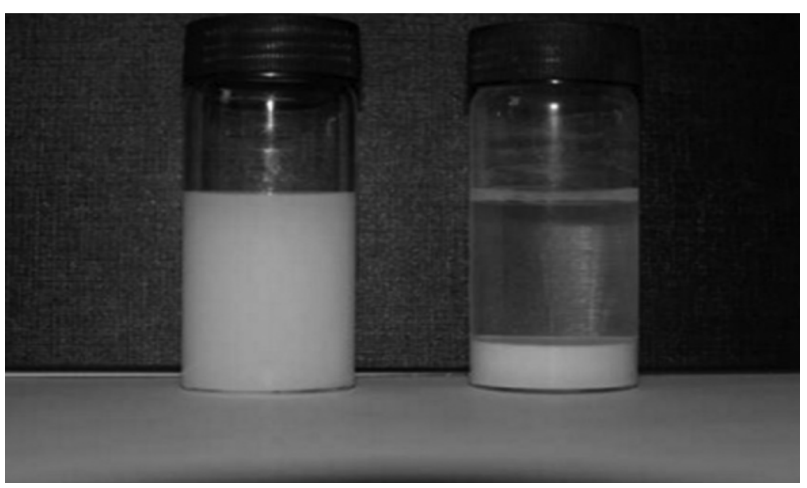

Figure 3. Stable(right) \& unstable(left) nanofluids

\subsection{Experimental rig set up}

Various experimental sets were set up by researchers in the heat transfer division of nanofluid applications. Most experiments use the same concept where a test section consisting of a number of temperature indicators is used together with a cooling reservoir and a few other data collecting devices attached for additional information besides the main results. Regular experimental set ups include supply tank, pumping device, heating tank, copper coil, gate valve, rotameter, test section, and a data acquisition system [39-41]. The main objective of the experimental set ups designed in past and future researches is to obtain the temperature drop of the car radiator to study the heat transfer properties of the experiment.

In an experiment by S. Zeinali Heris et al. [42], it was thoroughly explained that the experimental set-up consisted of a flow loop similar to the general experimental set up as shown in Figure 4. The $\mathrm{Al}_{2} \mathrm{O}_{3}$ nanofluid flows inside the inner tube while saturated steam entered annular section, which created constant wall temperature boundary condition. Flow rates were measured directly from time required to fill the glass vessel as one of the results of the nanofluid properties.

Figure 5 shows a schematic diagram similar to the experimental set up by S. Zeinali Heris et al. [42] was employed in an experimental study conducted by Maryamalsadat Lajvardi et al. [43]. Both aimed to find the heat transfer properties of different nanofluids. The former experimented on alumina trioxide while the later obtained the properties of ferric chloride. The flow loop of the experimental set up in Maryamalsadat's research included a peristaltic pump and a test section. Eight thermocouples are connected at throughout the heat transfer test section to measure the wall temperature. In order to minimize the heat loss from the test section, the whole test section was thermally isolated as done by S. Zeinali Heris. Both experiments were conducted towards a straight single circular tube.

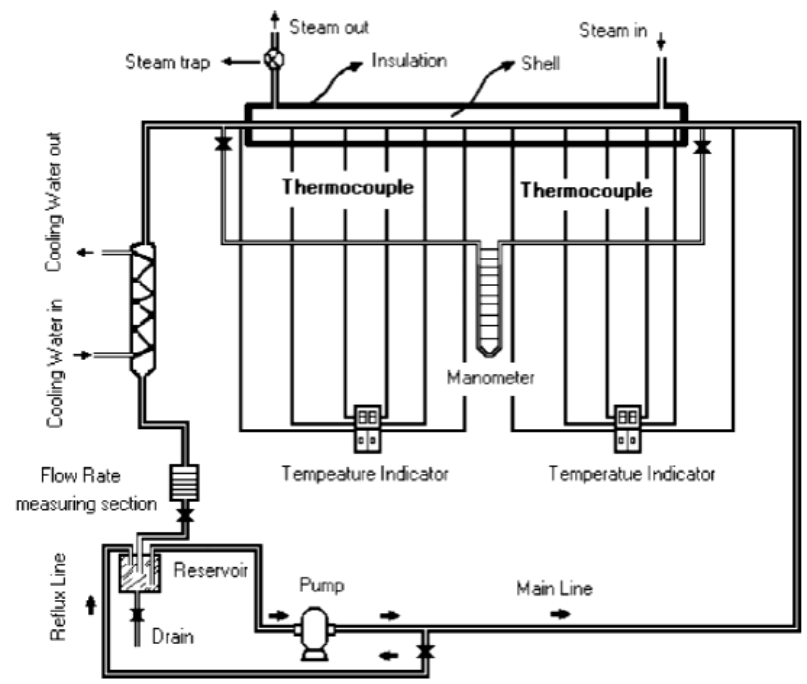

Figure 4. Experimental set up for $\mathrm{Al}_{2} \mathrm{O}_{3}$ nanofluid

In 2011, a similar experimental set was set up in an article from the Nanoscale Research Letters by Sundara Ramaprabhu et al. [44]. The flow loop included a pump with flow controlling valve system, a reservoir and a test section. Instead of eight, only four T-type thermocouples were mounted on the test section from the inlet of the test section to measure the wall temperature distribution, and two further T-type thermocouples were inserted into the flow at the inlet and exit of the test section to measure the bulk temperatures of nanofluids. This might be due to its size and has not affected the results of thermal properties. Similar to its predecessors, this experiment tested graphene nanofluid by changing its volume fraction percentage and Reynolds number to understand the heat transfer properties.

Another experiment on $\mathrm{Fe}_{3} \mathrm{O}_{4}$ was done to investigate the convection heat transfer and friction factor in 2011 by L. Syam Sundar et al. [45]. The experimental set up is as shown in Figure 6. The experimental setup consists of copper tube of internal diameter $0.014 \mathrm{~m}$, a chiller, collecting tank, a storage tank, data acquisition system, personal computer and pump. L Syam Sundar et al. has stated that the space between the test section and the outer casing is filled with rock wool insulation, differing from previously stated papers which used fiber glass for heat isolation. 


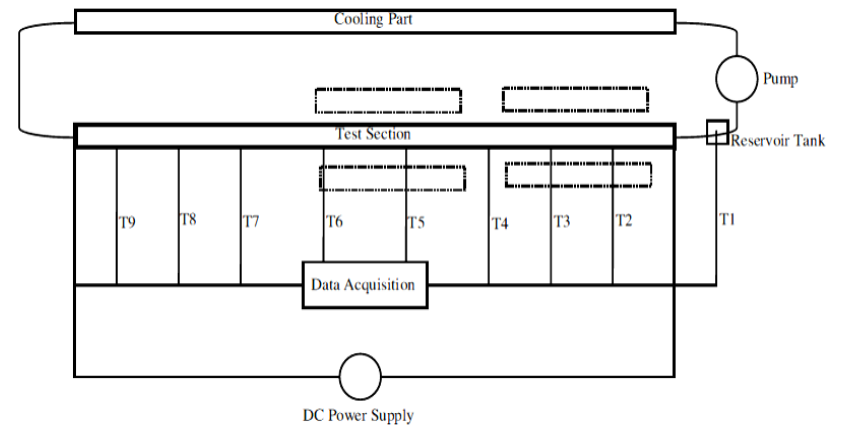

Figure 5. Experimental set up for $\mathrm{Fe}_{3} \mathrm{O}_{4}$ nanofluid

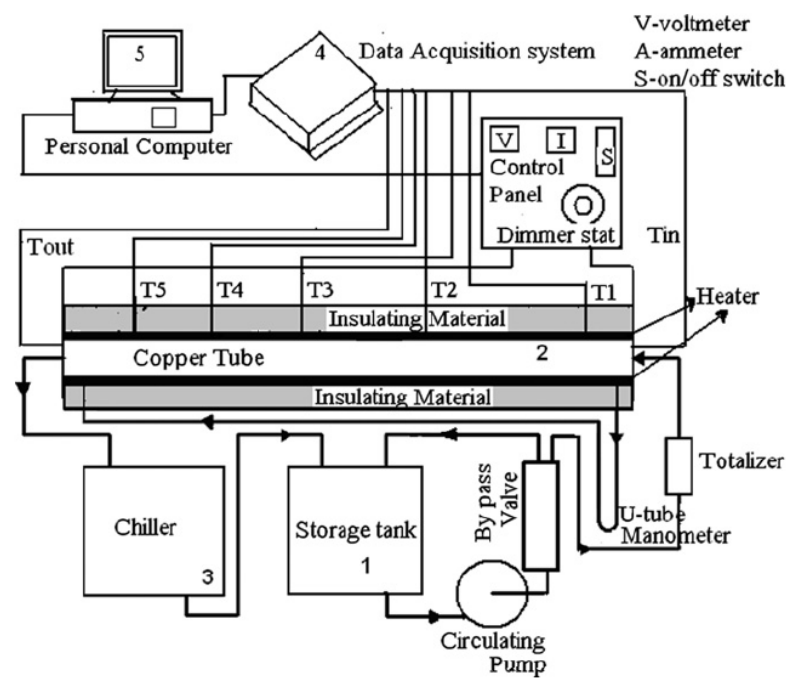

Figure 6. Experimental set up for $\mathrm{Fe}_{3} \mathrm{O}_{4}$ nanofluid

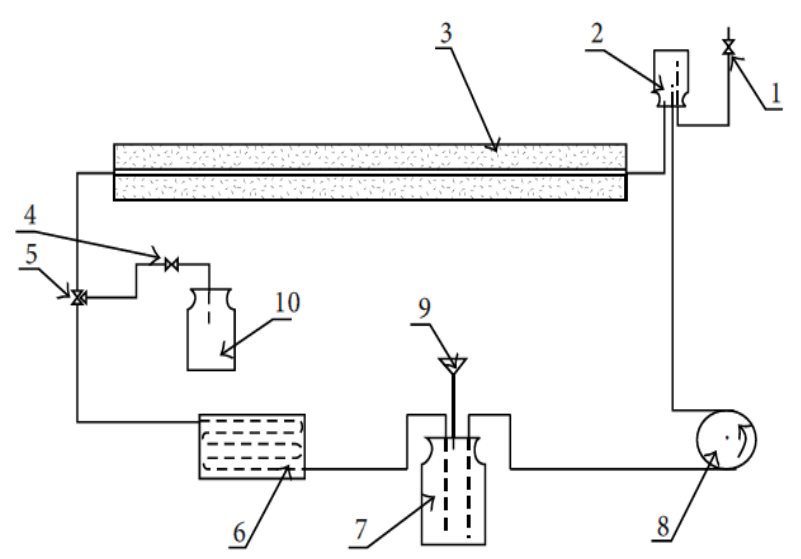

Figure 7. Experimental set up for $\mathrm{Fe}_{3} \mathrm{O}_{4}$ nanofluid

(1)Steam trap, (2)Water tank, (3)Test section, (4)Switch, (5)Vacuum valve, (6)Air cooler, (7) Reservoir tank, (8) Pump, (9) Funnel, (10) Collection tank

A self-made simplified experimental set was used by Jie Ma et al. [46] in 2013 as shown in schematic diagram in Figure 7. Although the experimental set up is simplified, the thermocouples used in this research was more than used in Sundara Ramaprabhu, Maryamalsadat and Zeinali Heris et al. Jie ma et al. used 14 thermocouples, which might have contributed to its more accurate and better results. As for the process of the experiment conducted, nanofluids flow inside the copper tube and pass through the test section for heat exchanger. The test chamber is covered by a heat-insulating shield with $10 \mathrm{~cm}$ thickness for blocking the heat lost. The flow rate of fluid is controlled and manipulated by a peristaltic type pump to ease the change of Reynolds number. This experiment specifically disposed the idea of conventional base liquids such as oil and ethylene glycol for its fewer adequacies for high heat flux application.

A more recent and specific research was done by $\mathrm{M}$. Naraki et al. [33] for the effects of copper oxide nanofluid on the $h$ when tested in a car radiator. This was one of the first tests experimented on an actual car radiator instead of a single tube. The schematic of experimental system, Figure 8, used in this experiment has a test section with a cross flow heat exchanger (an automobile radiator) which was installed inside the air flow channel and its configuration is the louvered fin-and-tube type.

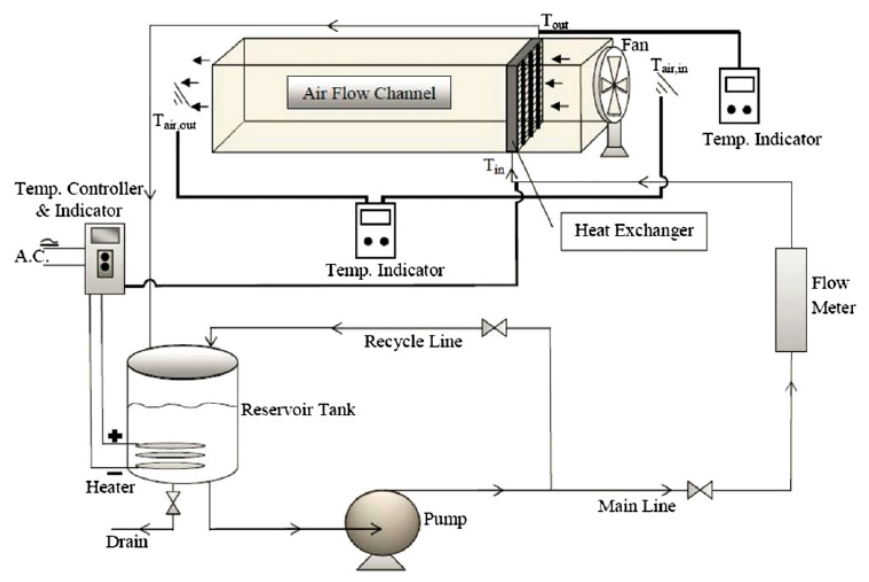

Figure 8. Experimental set up for $\mathrm{CuO}$ nanofluid

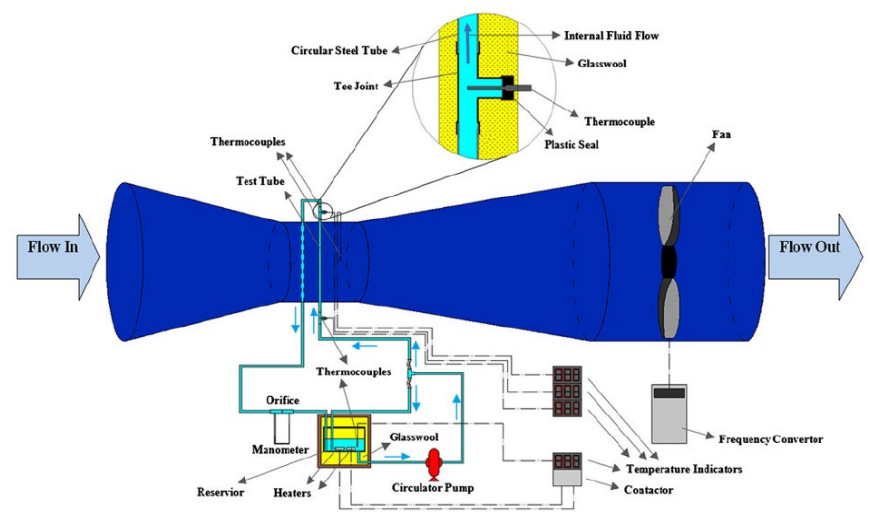

Figure 9. Experimental set up for Ag nanofluid

Also in the same year, Mansor Hemmati et al. [47] studied on the thermal conductivity of silver np in dilute water for use in the cross flow of air (tunnel). The experimental set up is shown in Figure 9. The test section was insulated with fibre glass to avoid heat loss to the environment. The ambient airflow was driven to the test section by a centrifugal fan. The rotations per minute of the wind tunnel fan and the air speed were controlled by an inverter which provided frequency control with different accuracies. The velocity of the cross flow of air was measured by a pitot-static tube.

In 2016, there were more experimental researches on alumina as thermal conductivity enhancers additional to the many journal papers in previous years. Figures 10-11 were from two distinguish papers published in early 2016 on the use of alumina as nanofluids for thermal property enhancement. 


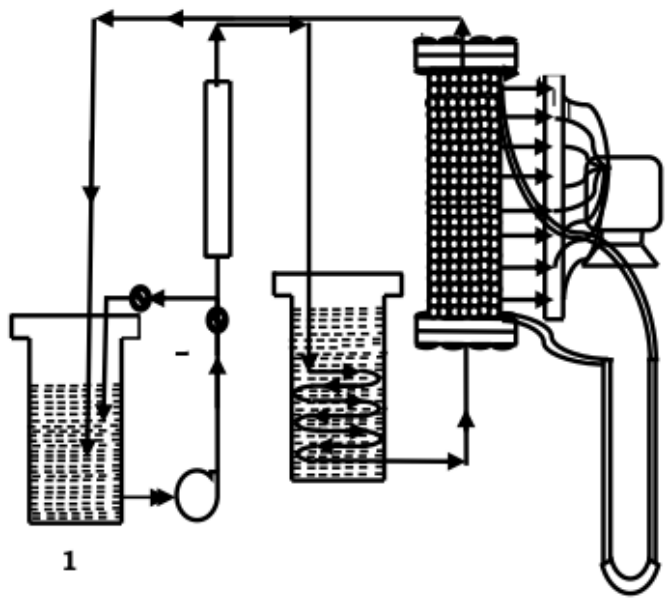

Figure 10. Experimental set up for $\mathrm{Al}_{2} \mathrm{O}_{3}$

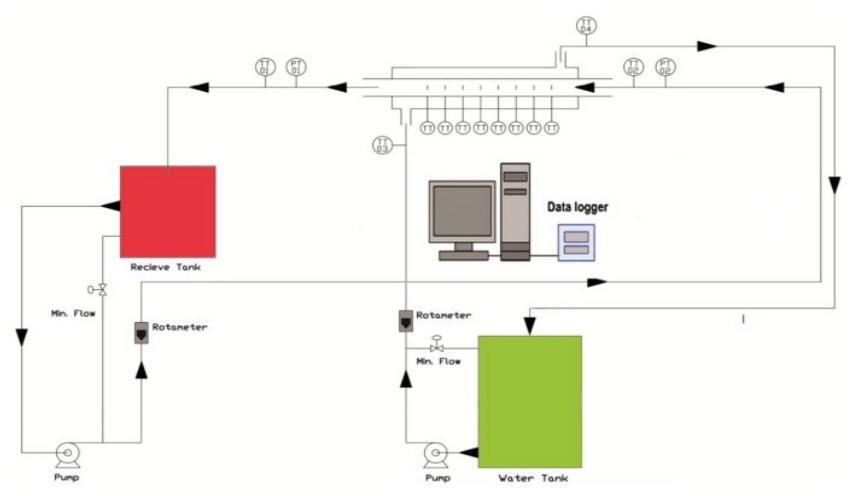

Figure 11. Experimental set up for ethylene glycol-based $\mathrm{Al}_{2} \mathrm{O}_{3}$

Figure 10 shows an experiment done by G. Srinivas Rao et al. [26] to investigate heat transfer properties of alumina nanofluid. Heydar Maddah et al. [27] published a research on alumina nanofluid with an experimental set as seen in Figure 11. The working fluids were circulated through the loop by using variable speed pumps of suitable capacity. As seen in the figures, both experiments were on alumina nanofluid but the setup is quite different. The former experiments under forced convection circumstance while the later studies the nanofluid properties with turbulent flow.

Rashid Pourrajab et al. [25] experimented with a similar experimental set with S Zeinali Heris and Maryamalsadat et al. Rashid Pourrajab et al. has experimented on alumina trioxide just as many of the previous papers did but under forced convection circumstances. Heat flux is adjusted by varying the voltage while the heat transfer section was isolated a thick insulation consisting of a layer of ceramic fiber blanket and a layer of ceramic fiber rope at the outer surface to prevent radial heat loss to the surroundings. The results were satisfying at $22.5 \%$ increase in heat transfer at $0.9 \%$ vol fraction while the increase in S Zeinali's were $47 \%$ at $1.6 \%$ vol fraction. This makes S. Zeinali Heris et al.'s research on a single tube higher in enhancement by $4.3 \%$.

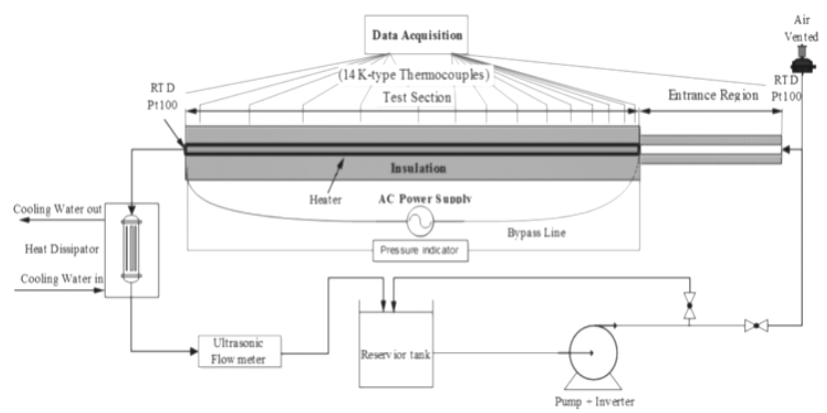

Figure 12. Experimental set up for graphene nanofluid

An experimental test bed was constructed by Hossein Akhavan-Zanjani et al. [48] and used to study the hydro dynamically fully developed laminar forced convection of the water-based Graphene nanofluid through a horizontal circular tube at constant wall heat flux in Figure 12, a complete opposite of the turbulent flow variable used in previous paper by Heyda Maddah et al. but similar in terms of nanofluid used.

A different approach was done by Sudev Das et al. [49] where comparison of heat transfer properties was done between untreated and treated, coated and uncoated copper heating surfaces instead of varying nanofluid vol fraction only. Nevertheless, the procedures lead to a similar purpose which is the enhancement of $h$. The set up in Figure 13 is the experimental set up designed in Sudev Das et al.'s research which resulted in a significant enhancement of heat transfer with treated silicon dioxide nanofluid coated with copper. Figure 14 is an experimental set up by Devanesan Madhesh et al. [50]. The directional flows relating to the hot and cold streams were set using the control valves in counter current mode such that the overall effectiveness of the heat exchanger was expected to be enhanced. The specially designed sample holding system was dedicated for thermal conductivity measurement of liquid samples.

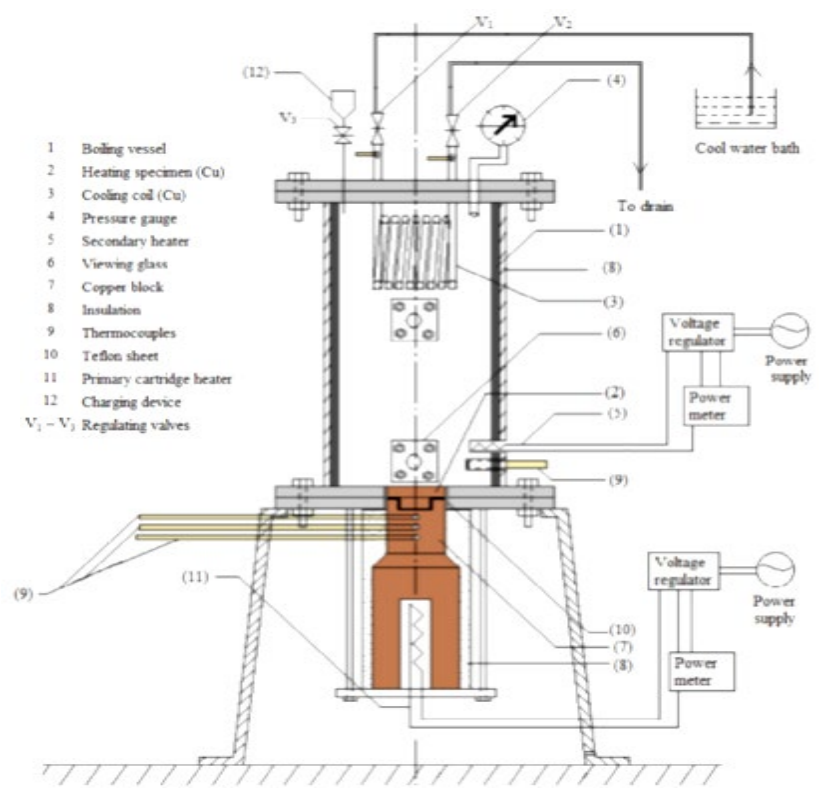

Figure 13. Experimental set up for $\mathrm{SiO}_{2}-\mathrm{CuO}$ nanofluid 


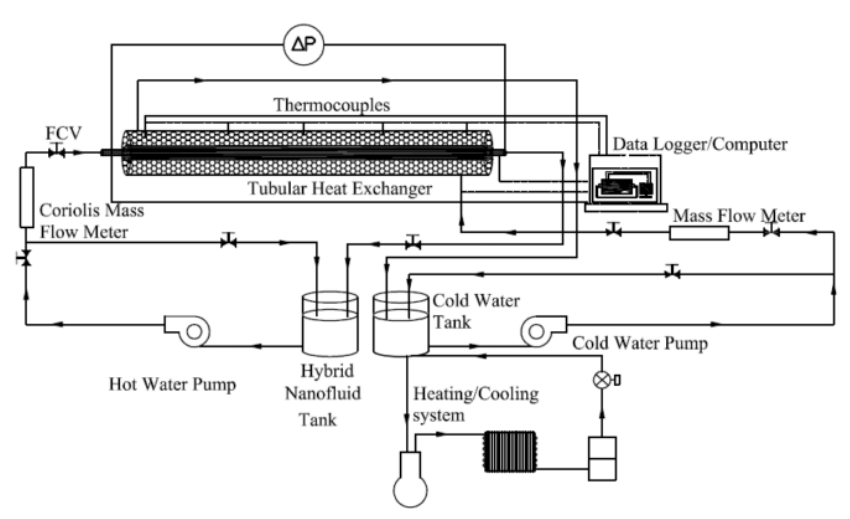

Figure 14. Experimental set up for $\mathrm{Ag} \& \mathrm{Cu}$ in tubular heat exchanger

Figure 15 shows a sketch of the experimental apparatus used in this study for measuring the convective $h$ in the laminar flow domain. The whole test section was heated by an element linked to an AC power supply to obtain a constant heat flux and to minimize the heat loss; a thermal insulating layer covered the heater as well. Wall temperature measurement was taken by the thermocouples at five equal intervals from each other. These temperatures were measured by the thermocouples directly, and then a signal was sent to the software sector [51].

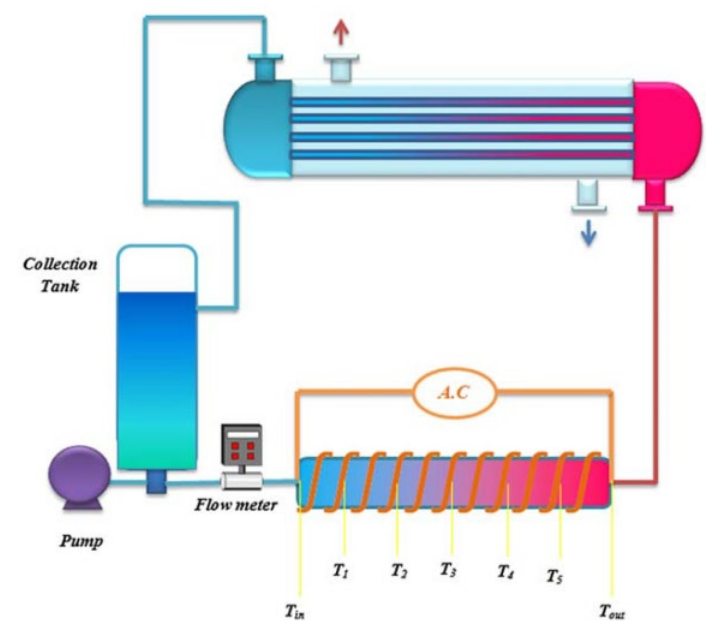

Figure 15. Experimental set up for $\mathrm{CNT}-\mathrm{TIO}_{2}$

Many more experiments were done on the thermal conductivity of nanofluids where diagrams of the experimental set up were not provided in their excerpt. Most of the experiments done using the same set up of either hot wires or consisting of a flow loop containing several sections such as temperature, pressure and flow rate measuring units, heating and cooling sections and flow controlling system. Some of these can be read about in journal articles by G. DeWitt et al., Songping Li et al, Xinwei Wang et al., J. A. Eastman et al., and Shou-Zhu Guo et al. [30, 49-52] etc.

Aside from experimental research, some researchers took a numerical approach to analyse the heat transfer conductivity of nanofluids. Said articles include the researches by John Philip et al., M. A. A. Hamad et al., S. M. Aminossadati et al., and M. Sheikholeslami et al. [4, 53-55] etc.

Mahdi Benzema et al. [56] wrote a research paper reporting a numerical investigation of steady and laminar mixed convection flow within an irregular ventilated enclosure, crossed by $\mathrm{Cu}$-Water nanofluid while $\mathrm{K}$. Ragui et al. [57] discussed the hydrodynamic and thermal characteristics of Ag-water nanofluid, filling a differentially heated cubic enclosure, numerically.

\subsection{Variables}

The most important part of the experiments is the variables taken into account in obtaining desired results. Although the variables manipulated are usually the same among most researches - volume fraction \%, some experiments change type of nanoparticle material [46]. A paper by Philip D. Myers Jr. et al. [18] focuses on temperature (melting points of materials) as a manipulated variable to investigate thermal properties while Fatih Selimefendigil et al. [58] focused on varying the $\mathrm{SiO}_{2}$ np' Rayleigh number. Weerapun Duangthongsuka et al. [59-60], in contrary, researched on the thermal performance and pressure-drop characteristics of nanofluid-cooled heat sinks by comparing their pin fin configurations besides the effect of nanofluid presence.

Table 1. Table of constant, manipulative, and responding variables

\begin{tabular}{c|c}
\hline Manipulated Variables & Responding Results \\
\hline Nanoparticle material & Thermal conductivity $(\mathrm{W} / \mathrm{m} \mathrm{K})$ \\
Nanoparticle size $(\mathrm{nm})$ & Specific heat capacity $(\mathrm{J} / \mathrm{kg} \mathrm{K})$ \\
Volume fraction $(\%)$ & Nanofluid density $\left(\mathrm{kg} / \mathrm{m}^{3}\right)$ \\
Base density $\left(\mathrm{kg} / \mathrm{m}^{3}\right)$ & Dynamic viscosity $\left(\mathrm{N} . \mathrm{s} / \mathrm{m}^{2}\right)$ \\
Temperature $(\mathrm{C})$ & Friction factor \\
Reynolds number & Nusselt number \\
\hline
\end{tabular}

Table 1 shows the variables, which are vastly used, that could be kept constant or manipulated by researchers based on their objectives and the results obtained for heat transfer efficiency analysis. Aside from the normal variables used, the most important variable that needs to be considered is the types of material used to make the nanofluid. The natural properties of the material used make the most significant difference in the resultant thermal conductivity. Based on recent studies, there have been countless experiments on alumina, copper and iron for their ability to enhance thermal conductivity efficiency. These nanoparticle used vary in decoration, size and volume fractions. Decorated nanofluids include diamond-copper, kerosene-alumina, silver-graphene, copper-HEG, and Ag-MWCNT [21, 38, 61-63] etc.; where most of their sizes vary between $20 \mathrm{~nm}-60 \mathrm{~nm}$. Although the concentrations of nanofluid dispersed in the base fluid are usually between $0.01 \%-2.5 \%$, some uses as low as $0.005 \%$ [41] and as high as $10 \%$ [45].

\section{RESEARCH RESULTS ANALYSIS: THERMAL CONDUCTIVITY}

Thermal conductivity has been the main interest of a good deal of researchers using nanofluids in applications. Based on previous researches, Table 2 is a summary on the most studied materials and their best results on thermal conductivity enhancement. It can be seen that as the volume concentration increases, the thermal conductivity subsequently increases. Several concluded that increase in temperature also resulted in a significant enhancement in thermal conductivity.

In line with that, the Reynolds number decreases with every increase of volume concentration, thus usually decreasing the 
Nusselt number and decreasing the ratio of convective to conductive heat transfer across the boundary. In few cases, though it is minor, the friction factor also increases due to increase of volume fraction. For example, in an experiment on $\mathrm{Fe}_{3} \mathrm{O}_{4}$ by L. Syam Sundar et al. [42], the $\mathrm{h}$ is enhanced by $30.96 \%$ while friction factor is increased by $10.01 \%$ at $0.6 \%$ volume concentration.

Table 2. Summary of thermal conductivity enhancement of nanofluids

\begin{tabular}{c|c|c|c}
\hline Material & $\begin{array}{c}\text { Volume } \\
\text { Fraction } \\
(\mathbf{\%})\end{array}$ & $\begin{array}{c}\text { Thermal } \\
\text { Conductivity } \\
\text { Enhancement } \\
(\%)\end{array}$ & $\begin{array}{c}\text { Referenc } \\
\text { es }\end{array}$ \\
\hline $\mathrm{Fe}_{3} \mathrm{O}_{4}$ & 7.8 & 23 & {$[53]$} \\
$\mathrm{CuO}$ & 0.4 & 8 & {$[33]$} \\
$\mathrm{MWCNT}$ in & 1.0 & 150 & {$[64]$} \\
Poly ( $\alpha-$ \\
olefin)oil
\end{tabular}

\section{DISCUSSION}

While alumina and copper are widely experimented with decoration of silver, kerosene and nitrate salts [18, 61, 38], the concept of decoration is indefinitely underexposed.

Graphene is one of the least explored nanofluids, with less than 40 researchers discussing on its heat transfer abilities alone and even lesser researchers experimenting with decorations of the nanofluid. With few repeated decoration materials by some researchers, Table 3 shows the known and published articles on decorated graphene used for thermal conductivity applications.

From Table 2, graphene in DI water has the highest thermal conductivity enhancement with the lowest volume fraction. From a $0.05 \%$ volume fraction of f-HEG dispersed DI water based nanofluid shows an enhancement in thermal conductivity of about $16 \%$ at $25^{\circ} \mathrm{C}$ and $75 \%$ at $50^{\circ} \mathrm{C}$.

All of the material coating the graphene as decoration has their own characteristics which can benefit several applications. $\mathrm{Au}$ has fluorescence, luminescence, and electrochemical characteristics that make it excellent sensory and environmental devices [67]. Based on the paper written by $\mathrm{Hu}$ et al. [70], silver has outstanding robustness upon being bent down 100 times to $5 \mathrm{~mm}$ with and without encapsulation. Paint \& Coatings Industry magazine [71] explained in an article that with the effect of heats of immersion of a particle in water, $\mathrm{SiO}_{2}$ is high up in the ranking of high solubility, at a level of 2-6 ppm, which makes it credible for solubility and heat transfer purposes while being economical. Nitrogen is said to remain covalently bounded to the surface of graphene in the form of hydrazones, amines, aziridines or other similar structures in an article by Wei Gao et al et al [68, 72-73]. Copper is generally known as a medium in enhancing heat transfer activities whereas the high permittivity of poly (vinylidene fluoride) attracted the interest for the polymer/graphene composite for heat transfer enhancement in an article in 2011 [69].

Table 3. Research on decorated graphene nanofluids

\begin{tabular}{|c|c|c|c|}
\hline $\begin{array}{c}\text { Material } \\
\text { Doped }\end{array}$ & Research & Results & Ref. \\
\hline $\mathrm{Au}$ & $\begin{array}{c}\text { Optical } \\
\text { properties }\end{array}$ & $\begin{array}{l}\text { SERS enhancement factors } \\
\text { of ranging from } 9 \text { to } 20\end{array}$ & [67] \\
\hline $\mathrm{Ag}$ & $\begin{array}{l}\text { Synthesis } \\
\text { and } \\
\text { application }\end{array}$ & $\begin{array}{c}\text { Synthesized successfully } \\
\text { without any surfactant } \\
0.01 \text { vol } \% \text { enhances } 122 \% \\
\text { h }\end{array}$ & [34] \\
\hline $\mathrm{SiO}_{2}$ & Stability & $\begin{array}{l}\text { Hydrophilicity, stability, } \\
\text { thermal conductivity } \\
\text { improved rather than using } \\
\text { surfactant (SDBS) }\end{array}$ & {$[50]$} \\
\hline Nitrogen & $\begin{array}{c}\text { Preparation, } \\
\text { characteriza } \\
\text { tion, } \\
\text { viscosity, } \\
\text { thermal } \\
\text { conductivity }\end{array}$ & $\begin{array}{c}0.06 \text { vol \% enhances } \\
36.78 \% \mathrm{~h}\end{array}$ & [68] \\
\hline $\mathrm{CuO}$ & $\begin{array}{l}\text { Synthesis } \\
\text { and } \\
\text { transport } \\
\text { properties }\end{array}$ & 0.05 vol $\%$ enhances $28 \% \mathrm{~h}$ & {$[62]$} \\
\hline $\begin{array}{l}\text { Poly(vinyl } \\
\text {-idene } \\
\text { fluoride) }\end{array}$ & $\begin{array}{l}\text { Permittivity, } \\
\text { thermal } \\
\text { conductivity } \\
\text { and thermal } \\
\text { stability }\end{array}$ & $\begin{array}{c}0.5 \text { vol \% enhances } 200 \% \text { h } \\
7.5 \text { vol \% had a permittivity } \\
\text { higher than } 300\end{array}$ & [69] \\
\hline $\begin{array}{c}\mathrm{Al}_{2} \mathrm{O}_{3} \\
\text { ceramics }\end{array}$ & $\begin{array}{l}\text { Thermal } \\
\text { energy } \\
\text { storage }\end{array}$ & $\begin{array}{l}\text { Low sheet electrical } \\
\text { resistance and high thermal } \\
\text { conductivity } \\
\text { graphene/ceramic nanofluid } \\
\text { may play important role in } \\
\text { thermal management } \\
\text { applications }\end{array}$ & [14] \\
\hline
\end{tabular}

Regarding the experimental rig set ups discussed, Table 4 analyses the nanofluids used and outcomes of each experiments.

Every experimental set up were designed specifically and intentionally by authors to investigate heat transfer properties. However, given that each equipment and components have significant advantages; authors have received different outcomes and delivered substantial results for further researchers to delve into optimizing experimental design to obtain optimum results based on research purposes.

It can be seen that the use of laminar or turbulent flow, number of thermocouples, types of test section and many more can have slight or heavy effect towards final results. One clear example of this is the difference between the experiments done by G. Srinivas Rao et al and Heydar Maddah et al on the heat transfer activities of $\mathrm{Al}_{2} \mathrm{O}_{3}$. Both researched on the same nanofluid but the former received a $14.6 \%$ increment in $\mathrm{h}$ with a $0.5 \mathrm{vol} \%$ while the later enhanced thermal activities by $4.2 \%$ with the same amount of $0.5 \mathrm{vol} \%$ of the nanofluid. Therefore it can be concluded that experimental set ups should be designed based on the author's sources and objectives; the results will differ. 
Table 4. Experimental design outcomes summary

\begin{tabular}{|c|c|c|}
\hline Experiment/Figure & Nanofluid & Outcome \\
\hline $\begin{array}{l}\text { S. Zeinali Heris et al. } \\
\text { (Fig. 4) }\end{array}$ & $\mathrm{Al}_{2} \mathrm{O}_{3}$ & $\begin{array}{l}\text { Increase in } \mathrm{h} \text { due to presence of np is much higher than the } \\
\text { prediction of single phase heat transfer correlation used with } \\
\text { nanofluid properties. }\end{array}$ \\
\hline $\begin{array}{l}\text { Maryamalsadat Lajvardi } \\
\text { et al. (Fig. 5) }\end{array}$ & $\mathrm{FeCl}_{3}$ & $\begin{array}{c}\mathrm{Fe}_{3} \mathrm{O}_{4} \text { magnetic np dispersed in water cannot enhance } \\
\text { convective heat transfer in laminar flow regime in the } \\
\text { absence of magnetic field but particularly significant under } \\
\text { the influence of an applied magnetic field and magnetic } \\
\text { nanoparticle volume fraction. }\end{array}$ \\
\hline $\begin{array}{l}\text { L. Syam Sundar et al. } \\
\text { (Fig. 6) }\end{array}$ & $\mathrm{Fe}_{3} \mathrm{O}_{4}$ & $\begin{array}{l}\mathrm{h} \text { is enhanced by } 30.96 \% \text { and friction factor by } 10.01 \% \text { at } \\
0.6 \% \text { volume concentration. }\end{array}$ \\
\hline Jie Ma et al. (Fig. 7) & $\mathrm{Fe}_{3} \mathrm{O}_{4}$ & $\begin{array}{l}\text { Increased concentration of np is disadvantage to improve the } \\
\text { forced } \mathrm{h} \text { under transition region with present investigated } \\
\text { conditions. }\end{array}$ \\
\hline M. Naraki et al. (Fig. 8) & $\mathrm{CuO}-\mathrm{H}_{2} \mathrm{O}$ & $\begin{array}{l}\mathrm{h} \text { increases with the enhancement in the nanofluid } \\
\text { concentration from } 0 \text { to } 0.4 \mathrm{vol} \% \text { and decreases with } \\
\text { increase of nanofluid inlet temperature from } 50 \mathrm{C} \text { to } 80 \mathrm{C} \text {. }\end{array}$ \\
\hline $\begin{array}{l}\text { Mansor Hemmati et al. } \\
\text { (Fig. 9) }\end{array}$ & Ag-DI & $\begin{array}{c}\text { Measured thermal conductance, ef- fectiveness, and external } \\
\mathrm{Nu} \text { are } \pm 4.1 \%, \pm 3.7 \% \text {, and } \pm 4.3 \% \text {, respectively with } \\
0.005 \%, 0.01 \% \text {, and } 0.02 \% \text { volume fraction. }\end{array}$ \\
\hline $\begin{array}{l}\text { G. Srinivas Rao et al. } \\
\text { (Fig. 10) }\end{array}$ & $\mathrm{Al}_{2} \mathrm{O}_{3}$ & $\begin{array}{l}\text { The enhancement in heat transfer with } 6 \mathrm{~mm} \text { glass beads, at } \\
\text { Reynolds number of } 500 \text { and } 3000 \text { is respectively greater by } \\
14.6 \% \text { for } 0.5 \% \text { nanofluid concentration. }\end{array}$ \\
\hline $\begin{array}{l}\text { Heydar Maddah et al. } \\
\text { (Fig. 11) }\end{array}$ & $\mathrm{Al}_{2} \mathrm{O}_{3}$ & $\begin{array}{l}\text { Maximum thermal enhancement at } 4.2 \% \text { with } \mathrm{Al}_{2} \mathrm{O}_{3} / \mathrm{EG} \\
\text { nanofluid } 0.5 \mathrm{vol} \% \text { in corrugated tube with twisted tape at } \\
\text { twist ratio } 2 .\end{array}$ \\
\hline $\begin{array}{l}\text { Hossein Akhavan- } \\
\text { Zanjani et al. (Fig. 12) }\end{array}$ & Graphene & $\begin{array}{c}\text { Enhancement } 10.3 \% \text { for thermal conductivity and } 14.2 \% \text { for } \\
\mathrm{h} \text { at Re } 1850 \text { with } 0.02 \mathrm{vol} \% \text { in a laminar forced heat } \\
\text { transfer inside a circular tube. }\end{array}$ \\
\hline $\begin{array}{l}\text { Sudev Das et al. (Fig. } \\
13 \text { ) }\end{array}$ & $\mathrm{SiO}_{2}-\mathrm{CuO}$ & $\begin{array}{l}\text { Electron beam physical vapor deposition (EBPVD) coating } \\
\text { approach used to fabricate nanofluid which caused } \\
\text { reduction of about } 36 \% \text { in the incipience superheat and } 58 \% \\
\text { enhancement in h. }\end{array}$ \\
\hline $\begin{array}{l}\text { Devanesan Madhesh et } \\
\text { al(Fig. 14) }\end{array}$ & $\mathrm{Ag} \& \mathrm{Cu}$ & $\begin{array}{c}\text { At nanofluid } 1.0 \mathrm{vol} \%, \mathrm{~h} \text { and } \mathrm{Nu} \text { were augmented by } 52 \% \\
\text { and } 47.5 \% \text { for } \mathrm{Ag} \text { nanofluids, } 27.6 \% \text { and } 24.3 \% \text { for } \mathrm{CuO} \\
\text { nanofluids, respectively, in turbulent flow. }\end{array}$ \\
\hline $\begin{array}{l}\text { L. Megatif et al. (Fig. } \\
\text { 15) }\end{array}$ & $\mathrm{CNT}-\mathrm{TiO}_{2}$ & $\begin{array}{l}\text { Significant enhancement of h (about } 38 \% \text { ) was achieved by } \\
\text { using } 0.2 \mathrm{wt} \% \mathrm{CNT}-\mathrm{TiO}_{2} \text { hybrid NFs at } 38 \mathrm{C} \text { in laminar } \\
\text { flow. }\end{array}$ \\
\hline
\end{tabular}

\section{CONCLUSIONS}

Based on previous literatures, many applications would be more efficient with the help of nanofluids. It is concluded that the presence of nanofluids generally increases the $h$ and thermal conductivity. Aside from that, other properties such as stability, hydrophilicity, and electrical resistance could also be enhanced with the right nanofluids used.

It is clear that there is much more space to explore in the nanofluid research community especially doped and decorated nanofluids. Decorated nanofluids help enhance all characteristics. While graphene np have excellent heat transfer properties as an individual nanofluid, doped graphene np portrayed higher potential in heat transfer and other applications as well. Copper oxide doped on graphene $\mathrm{np}$, as the most used decorated np, caused an enhancement of $28 \%$ in thermal conductivity with 0.05 vol $\%$ while graphene nanofluid increased $16 \%$ of heat transfer with the same 0.05 vol\%. Additionally, silver excels in stability causing silver doped graphene nanofluids to be synthesized without any surfactants. Obviously, further research of unlikely pairs of doped $\mathrm{np}$ for nanofluids could be done in the future for exploration of higher purposes of nanofluids.
Furthermore, having stability and cost of nanofluid preparation and experimental rigs is a major issue in the nanofluid industry. Actual heat exchangers used in the industry are also increasing in price by the week due to the economy. Further commercialization and additions to theoretical and experimental research is suspected to solve these challenges while increasing the potential of nanofluids.

The various methods of experimental research for thermal conductivity were summarized efficiently in this review paper. Heat transfer related experiments for nanofluids were analyzed and the slight change in research objectives definitely changes in the setup of experimental rigs. Although the experimental methods were common and almost alike among most researchers, methods of nanofluid preparation are inconsistent between many researchers.

\section{ACKNOWLEDGMENT}

This study is funded by FRGS grant, UNITEN/RMC.15/5/370 provided by ministry of education, Malaysia. 


\section{REFERENCES}

[1] Choi SU. (1998). Nanofluid technology: To be presented at the second Korean-American scientists and engineers association research. Technology.

[2] Puliti G, Paolucci S, Sen M. (2012). Nanofluids and their properties. Appl. Mech. Rev 64(3): 30803.

[3] Sheikholeslami M, Ganji DD. (2015). Nanofluid flow and heat transfer between parallel plates considering Brownian motion using DTM. Comput. Methods Appl. Mech. Eng. 283: 651-663. https://doi.org/10.1016/j.cma.2014.09.038

[4] Sheikholeslami M, Ashorynejad HR, Rana P. (2016). Lattice Boltzmann simulation of nanofluid heat transfer enhancement and entropy generation. J. Mol. Liq 214: 86-95. https://doi.org/10.1016/j.molliq.2015.11.052

[5] Sheikholeslami M, Gorji-Bandpy M, Ganji DD, Soleimani S. (2013). Effect of a magnetic field on natural convection in an inclined half-annulus enclosure filled with $\mathrm{Cu}$-water nanofluid using CVFEM. Adv. Powder Technol 24(6): 980-991. https://doi.org/10.1016/j.apt.2013.01.012

[6] Tohidi A, Ghaffari H, Nasibi H, Mujumdar AS. (2015). Heat transfer enhancement by combination of chaotic advection and nanofluids flow in helically coiled tube. Appl. Therm. Eng 86: 91-105. https://doi.org/10.1016/j.applthermaleng.2015.04.043

[7] For V. Hybrid Radiator-Cooling System.

[8] Dubouil R, Hetet JF, Maiboom A. (2013). A phenomenological heat transfer model of si engines application to the simulation of a full-hybrid vehicle. Oil Gas Sci. Technol. D Ifp Energies Nouv 68(1): 5163. https://doi.org/10.2516/ogst/2012031

[9] Huminic G, Huminic A. (2012). Application of nanofluids in heat exchangers: A review. Renew. Sustain. Energy Rev 16(8): 5625-5638. https://doi.org/10.1016/j.rser.2012.05.023

[10] Wong KV, Leon OD. (2010). Applications of nanofluids: Current and future. Adv. Mech. Eng 2010(January):

$0-11$. https://doi.org/10.1155/2010/519659

[11] Varga G. Development and demonstration of nanofluids for industrial cooling applications please contact.

[12] Buongiorno J, Hu LW, Kim SJ, Hannink R, Truong B, Forrest E. (2008). Nanofluids for enhanced economics and safety of nuclear reactors: An evaluation of the potential features, issues, and research gaps. Nucl. Technol 162(1): 80-91. https://doi.org/10.1016/j.nimb.2007.10.042

[13] Hadad K, Rahimian A, Nematollahi MR. (2013). Numerical study of single and two-phase models of water $/ \mathrm{Al}_{2} \mathrm{O}_{3}$ nanofluid turbulent forced convection flow in VVER-1000 nuclear reactor. Ann. Nucl. Energy 60: 287-294. https://doi.org/10.1016/j.anucene.2013.05.017

[14] Zhou M, Lin TQ, Huang FQ, Zhong YJ, Wang Z, Tang YF, Bi H. (2013). Highly conductive porous graphene/ceramic composites for heat transfer and thermal energy storage. Adv. Funct. Mater 23(18): 2263-2269. https://doi.org/10.1002/adfm.201202638

[15] Saidur R, Leong KY, Mohammad HA. (2011). A review on applications and challenges of nanofluids. Renew. Sustain. Energy Rev 15(3): 1646-1668. https://doi.org/10.1016/j.rser.2010.11.035

[16] Rashmi W, Ismail AF, Khalid M, Faridah Y. (2011). CFD studies on natural convection heat transfer of $\mathrm{Al}_{2} \mathrm{O}_{3}$-water nanofluids. January 1301-1310.

[17] Saxena R, Gangacharyulu D, Bulasara VK. (2016). Heat transfer and pressure drop characteristics of dilute alumina-water nanofluids in a pipe at different power inputs. Heat Transf. Eng 7632(February): 00-00. https://doi.org/10.1080/01457632.2016.1151298

[18] Myers PD, Alam TE, Kamal R, Goswami DY, Stefanakos E. (2016). Nitrate salts doped with $\mathrm{CuO} n p$ for thermal energy storage with improved heat transfer. Appl. $\quad$ Energy 225-233. https://doi.org/10.1016/j.apenergy.2015.11.045

[19] Vajjha RS, Das DK, Ray DR. (2014). Development of new correlations for the Nusselt number and the friction factor under turbulent flow of nanofluids in flat tubes. Int. J. Heat Mass Transf 80(March 2016): 353-367. https://doi.org/10.1016/j.ijheatmasstransfer.2014.09.01 8

[20] Gunnasegaran P, Shuaib NH, Abdul Jalal MF. (2012). The effect of geometrical parameters on heat transfer characteristics of compact heat exchanger with louvered fins. ISRN Thermodyn 2012: 1-10.

[21] Ma HB, Wilson C, Borgmeyer B, Park K, Yu Q, Choi SUS, Tirumala M. (2006). Effect of nanofluid on the heat transport capability in an oscillating heat pipe. Appl. Phys. Lett 88: 14 https://doi.org/10.1063/1.2192971

[22] Deng Y, Li Y, Dai J, Lang M, Huang X. (2011). An efficient way to functionalize graphene sheets with presynthesized polymer via ATNRC chemistry. J. Polym. Sci. Part A Polym. Chem 49(7): 1582-1590. https://doi.org/10.1002/pola.24579

[23] Solangi KH, Kazi SN, Luhur MR, Badarudin A, Amiri A, Sadri R, Zubir MNM, Gharehkhani S, Teng KH. (2015). A comprehensive review of thermo-physical properties and convective heat transfer to nanofluids. Energy 89(February 2016): 1065-1086. https://doi.org/10.1016/j.energy.2015.06.105

[24] Yu W, Xie H. (2012). A review on nanofluids: Preparation, stability mechanisms, and applications. J. Nanomater 2012. https://doi.org/10.1155/2012/435873

[25] Noghrehabadi A, Pourrajab R. (2016). Experimental investigation of forced convective heat transfer enhancement of $\gamma-\mathrm{Al}_{2} \mathrm{O}_{3} /$ water nanofluid in a tube. $\mathrm{J}$. Mech. Sci. Technol 30(2): 943-952. https://doi.org/10.1007/s12206-016-0148-z

[26] Srinivasrao G, Rao PV. (2016). Numerical and experimental investigation of packed bed thermal energy storage system with $\mathrm{Al}_{2} \mathrm{O}_{3}$ Nanofluid. Int. Res. J. Eng. Technol 3(1): 582-590.

[27] Aghayari R, Maddah H, Zarei M, Dehghani M, Kaskari Mahalle SG. (2014). Heat transfer of nanofluid in a double pipe heat exchanger. Int. Sch. Res. Not 2014: 17. https://doi.org/10.1155/2014/736424

[28] Sridhara V, Satapathy LN. (2011). $\mathrm{Al}_{2} \mathrm{O}_{3}$-based nanofluids : A review. pp. 1-16.

[29] Lee S, Choi SUS, Li S, Eastman JA. (1999). Measuring thermal conductivity of fluids containing oxide np. J. Heat Transfe 121(2): 280-289.

[30] Eastman JA, Choi SUS, Li S, Yu W, Thompson LJ. (2001). Anomalously increased effective thermal conductivities of ethylene glycol-based nanofluids 
containing copper np. Appl. Phys. Lett 78(6): 718-720. https://doi.org/10.1063/1.1341218

[31] Jana S, Salehi-Khojin A, Zhong WH. (2007). Enhancement of fluid thermal conductivity by the addition of single and hybrid nano-additives. Thermochim. Acta 462(1-2): 45-55. https://doi.org/10.1016/j.tca.2007.06.009

[32] Wang XQ, Mujumdar AS. (2007). Heat transfer characteristics of nanofluids: A review. Int. J. Therm. Sci 46(1): 1-19. https://doi.org/10.1016/j.ijthermalsci.2006.06.010

[33] Peyghambarzadeh SM, Hashemabadi SH, Naraki M, Vermahmoudi Y. (2013). Experimental study of overall heat transfer coef fi cient in the application of dilute nano fluids in the car radiator. Int. J. Therm. Sci 52: 816. https://doi.org/10.1016/j.applthermaleng.2012.11.013

[34] Zainy M, Huang NM, Vijay Kumar S, Lim HN, Chia CH, Harrison I. (2012). Simple and scalable preparation of reduced graphene oxide-silver nanocomposites via rapid thermal treatment. Mater. Lett 89(January): 180183. https://doi.org/10.1016/j.matlet.2012.08.101

[35] Kazi SN, Badarudin A, Zubir MNM, Huang NM, Misran M, Sadeghinezhad E, Mehrali M, Syuhada NI. (2015). Investigation on the use of graphene oxide as novel surfactant to stabilize weakly charged graphene nanoplatelets. Nanoscale Res. Lett 10(1): 212. https://doi.org/10.1186/s11671-015-0882-7

[36] Liang J, Huang Y, Zhang L, Wang Y, Ma YF, Guo TY, Chen YS. (2009). Molecular-level dispersion of graphene into poly (vinyl alcohol) and effective reinforcement of their nanocomposites. Adv. Funct. Mater 19(14): 2297-2302. https://doi.org/10.1002/adfm.200801776

[37] Shahrul IM, Mahbubul IM, Khaleduzzaman SS, Saidur R, Sabri MFM. (2014). A comparative review on the specific heat of nanofluids for energy perspective. Renew. Sustain. Energy Rev 38: 88-98. https://doi.org/10.1016/j.rser.2014.05.081

[38] Baby TT, Ramaprabhu S. (2011). Synthesis and nanofluid application of silver np decorated graphene. J. $\begin{array}{llll}\text { Mater. } & \text { Chem } & 21(26) \text { : } & 9702 .\end{array}$ https://doi.org/10.1039/c0jm04106h

[39] Zeinali Heris S, Nasr Esfahany M, Etemad SG. (2007). Experimental investigation of convective heat transfer of $\mathrm{Al}_{2} \mathrm{O}_{3}$ /water nanofluid in circular tube. Int. J. Heat Fluid Flow 28(2): 203-210.

[40] Lajvardi M, Moghimi-Rad J, Hadi I, Gavili A, Dallali Isfahani T, Zabihi F, Sabbaghzadeh J. (2010). Experimental investigation for enhanced ferrofluid heat transfer under magnetic field effect. J. Magn. Magn. Mater 322(21): 3508-3513. https://doi.org/10.1016/j.jmmm.2010.06.054

[41] Baby TT, Ramaprabhu S. (2011). Enhanced convective heat transfer using graphene dispersed nanofluids. Nanoscale Res. Lett 6(1): 289. https://doi.org/10.1186/1556-276X-6-289

[42] Syam Sundar L, Naik MT, Sharma KV, Singh MK, Siva Reddy TC. (2012). Experimental investigation of forced convection heat transfer and friction factor in a tube with $\mathrm{Fe}_{3} \mathrm{O}_{4}$ magnetic nanofluid. Exp. Therm. Fluid Sci 37: 65-71. https://doi.org/10.1016/j.expthermflusci.2011.10.004

[43] Ma J, Xu Y, Li W, Zhao J, Zhang S, Basov S. (2013).
Experimental investigation into the forced convective heat transfer of aqueous $\mathrm{Fe}_{3} \mathrm{O}_{4}$ nanofluids under transition region. J. $\mathrm{Np}$ 2013: 1-5. https://doi.org/10.1155/2013/601363

[44] Mohammadian S, Layeghi M, Hemmati M. (2013). Experimental study of forced convective heat transfer from a vertical tube conveying dilute $\mathrm{Ag} / \mathrm{DI}$ water nanofluids in a cross flow of air. Int. Nano Lett 3(1): 15. https://doi.org/10.1186/2228-5326-3-15

[45] Akhavan-Zanjani H, Saffar-Avval M, Mansourkiaei M, Sharif F, Ahadi M. (2016). Experimental investigation of laminar forced convective heat transfer of Graphenewater nanofluid inside a circular tube. Int. J. Therm. Sci 100: 316-323. https://doi.org/10.1016/j.ijthermalsci.2015.10.003

[46] Das S, Kumar DS, Bhaumik S. (2016). Experimental study of nucleate pool boiling heat transfer of water on silicon oxide nanoparticle coated copper heating surface. Appl. Therm. Eng 96: 555-567. https://doi.org/10.1016/j.applthermaleng.2015.11.117

[47] Madhesh D, Parameshwaran R, Kalaiselvam S. (2016). Experimental studies on convective heat transfer and pressure drop characteristics of metal and metal oxide nanofluids under turbulent flow regime. Heat Transf. Eng 37(5): https://doi.org/10.1080/01457632.2015.1057448

[48] Megatif L, Ghozatloo A, Arimi A, Shariati-Niasar M. (2015). Investigation of laminar convective heat transfer of a novel $\mathrm{TiO}_{2}$-carbon nanotube hybrid waterbased nanofluid. Exp. Heat Transf 6152(November): 115. https://doi.org/10.1080/08916152.2014.973974

[49] Dewitt G, McKrell T, Buongiorno J, Hu LW, Park RJ. (2013). Experimental study of critical heat flux with alumina-water nanofluids in downward-facing channels for In-Vessel retention applications. Nucl. Eng. Technol 45(3):

335-346. https://doi.org/10.5516/NET.02.2012.075

[50] Li X, Chen Y, Mo S, Jia L, Shao X. (2014). Effect of surface modification on the stability and thermal conductivity of water-based $\mathrm{SiO}_{2}$-coated graphene nanofluid. Thermochim. Acta 595: 6-10. https://doi.org/10.1016/j.tca.2014.09.006

[51] Yu W, Xie H, Wang X, Wang X. (2011). Significant thermal conductivity enhancement for nanofluids containing graphene nanosheets. Phys. Lett. Sect. A Gen. At. Solid State Phys 375(10): 1323-1328. https://doi.org/10.1016/j.physleta.2011.01.040

[52] Guo SZ, Li Y, Jiang JS, Xie HQ. (2010). Nanofluids containing $\gamma-\mathrm{Fe}_{2} \mathrm{O}_{3}$ np and their heat transfer enhancements. Nanoscale Res. Lett 5(7): 1222-1227. https://doi.org/10.1007/s11671-010-9630-1

[53] Philip J, Shima PD, Raj B. (2007). Enhancement of thermal conductivity in magnetite based nanofluid due to chainlike structures. Appl. Phys. Lett 91(20): 203205. https://doi.org/10.1063/1.2812699

[54] Hamad MAA, Pop I, Md Ismail AI. (2011). Magnetic field effects on free convection flow of a nanofluid past a vertical semi-infinite flat plate. Nonlinear Anal. Real World Appl 12(3): 1338-1346. https://doi.org/10.1016/j.nonrwa.2010.09.014

[55] Aminossadati SM, Raisi A, Ghasemi B. (2011). Effects of magnetic field on nanofluid forced convection in a partially heated microchannel. Int. J. Non. Linear. Mech 46(10):

1373-1382. 
https://doi.org/10.1016/j.ijnonlinmec.2011.07.013

[56] Benzema M, Benkahla YK, Labsi N, Brunier E, Ouyahia SE. (2017). Numerical mixed convection heat transfer analysis in a ventilated irregular enclosure crossed by $\mathrm{Cu}-$ Water nanofluid. Arab. J. Sci. Eng 42(11): 4575-4586. https://doi.org/10.1007/s13369017-2563-6

[57] Boutra A, Ragui K, Labsi N, Bennacer R, Benkahla YK. (2016). Natural convection heat transfer of a nanofluid into a cubical enclosure: Lattice boltzmann investigation. Arab. J. Sci. Eng 41(5): 1969-1980. https://doi.org/10.1007/s13369-016-2052-3

[58] Selimefendigil F, Öztop HF, Abu-Hamdeh N. (2016). Mixed convection due to rotating cylinder in an internally heated and flexible walled cavity filled with $\mathrm{SiO}_{2}$-water nanofluids: Effect of nanoparticle shape. Int. Commun. Heat Mass Transf 71: 9-19. https://doi.org/10.1016/j.icheatmasstransfer.2015.12.0 07

[59] Duangthongsuk W, Wongwises S. (2015). A comparison of the heat transfer performance and pressure drop of nanofluid-cooled heat sinks with different miniature pin fin configurations. Exp. Therm. Fluid Sci 69: 111-118. https://doi.org/10.1016/j.expthermflusci.2015.07.019

[60] Duangthongsuk W, Wongwises S. (2009). Measurement of temperature-dependent thermal conductivity and viscosity of $\mathrm{TiO}_{2}$-water nanofluids. Exp. Therm. Fluid Sci 33(4): 706-714.

[61] Agarwal DK, Vaidyanathan A, Sunil Kumar S. (2013). Synthesis and characterization of kerosene-alumina nanofluids. Appl. Therm. Eng 60(1-2): 275-284. https://doi.org/10.1016/j.applthermaleng.2013.06.049

[62] Baby TT, Sundara R. (2011). Synthesis and transport properties of metal oxide decorated graphene dispersed nanofluids. J. Phys. Chem. C 115(17): 8527-8533. https://doi.org/10.1021/jp200273g

[63] Huang D, Wu Z, Sunden B. (2016). Effects of hybrid nanofluid mixture in plate heat exchangers. Exp. Therm. Fluid Sci 72: 190-196. https://doi.org/10.1016/j.expthermflusci.2015.11.009

[64] Wang X, Xu X, Choi SUS. (1999). Thermal conductivity of nanoparticle - fluid mixture. J. Thermophys. Heat Transf. 13(4): 474-480. https://doi.org/10.2514/2.6486

[65] Pradhan NR, Duan H, Liang J, Iannacchione GS. (2009). The specific heat and effective thermal conductivity of composites containing single-wall and multi-wall carbon nanotubes. Nanotechnology 20(24): 245705.

[66] Murshed SMS, Leong KC, Yang C. (2008). Thermophysical and electrokinetic properties of nanofluids - A critical review. Appl. Therm. Eng 28(1718): 2109-2125. https://doi.org/10.1016/j.applthermaleng.2008.01.005

[67] Yu J, Huang X, Wu C, Jiang P. (2011). Permittivity, thermal conductivity and thermal stability of poly(vinylidene fluoride)/graphene nanocomposites. IEEE Trans. Dielectr. Electr. Insul 18(2): 478-484. https://doi.org/10.1109/TDEI.2011.5739452

[68] Balandin AA. (2011). Thermal properties of graphene, carbon nanotubes and nanostructured carbon materials. Nat. Mater 10: 569-581. https://doi.org/10.1038/nmat3064

[69] Ahammed N, Asirvatham LG, Wongwises S. (2016). Effect of volume concentration and temperature on viscosity and surface tension of graphene-water nanofluid for heat transfer applications. J. Therm. Anal. Calorim 123(2): 1399-1409. https://doi.org/10.1007/s10973-015-5034-X

[70] Wang M, Jamal R, Wang Y, Yang L, Liu F, Abdiryim T. (2015). Functionalization of graphene oxide and its composite with poly (3,4-ethylenedioxythiophene) as electrode material for supercapacitors. Nanoscale Res. Lett 10(1): 370.

[71] Park SD, Lee SW, Sarah K, Bang IC, Kim JH, Shin HS, Lee DW, Lee DW. (2010). Effects of nanofluids containing graphene/graphene-oxide nanosheets on critical heat flux. Appl. Phys. Lett 97(2). https://doi.org/10.1063/1.3459971

[72] Gupta SS. Siva MV, Krishnan S, Sreeprasad TS, Singh PK, Pradeep T, Das SK. (2011). Thermal conductivity enhancement of nanofluids containing graphene nanosheets. J. Appl. Phys 110: 84302. https://doi.org/10.1063/1.3650456

[73] Fan LW, Li JQ, Li DY, Zhang L, Yu ZT, Cen KF. (2015). The effect of concentration on transient pool boiling heat transfer of graphene-based aqueous nanofluids. Int. J. Therm. Sci 91: 83-95. https://doi.org/10.1016/j.ijthermalsci.2015.01.009

[74] Lee YH, Polavarapu L, Gao N, Yuan P, Xu QH. (2012). Enhanced optical properties of graphene oxide-Au nanocrystal composites. Langmuir 28(1): 321-326. https://doi.org/10.1021/la204047a

[75] Mehrali M, Sadeghinezhad E, Latibari ST, Mehrali M, Togun H, Zubir MNM, Kazi SN, Metselaar HSC. (2014). Preparation, characterization, viscosity, and thermal conductivity of nitrogen-doped graphene aqueous nanofluids. J. Mater. Sci 49(20): 7156-7171. https://doi.org/10.1007/s10853-014-8424-8

[76] Hu L, Kim HS, Lee J, Peumans P, Cui Y. (2010). Scalable coating and properties of transparent ag nanowire. ACS Nano 4(5): 2955-2963. https://doi.org/10.1021/nn1005232

[77] Gunnasegaran P, Abdullah MZ, Yusoff MZ, Abdullah SF. (2015). Optimization of $\mathrm{SiO}_{2}$ nanoparticle mass concentration and heat input on a loop heat pipe. Case Stud. Therm. Eng 6: 238-250. https://doi.org/10.1016/j.csite.2015.10.004

[78] Gao W. (2015). The chemistry of graphene oxide', Graphene Oxide Reduct. Recipes, Spectrosc. Appl pp. 61-95.

[79] Yang P, Li X, Yang H, Wang X, Tang Y, Yuan X. (2013). Numerical investigation on thermal conductivity and thermal rectification in graphene through nitrogen-doping engineering. Appl. Phys. A Mater. Sci. Process 112(3): 759-765. https://doi.org/10.1007/s00339-013-7607-5

\section{NOMENCLATURE}

$\mathrm{T}$

CP

g

$\mathrm{k}$

h
Thermocouple

Specific heat, $\mathrm{J} . \mathrm{kg}^{-1}$. $\mathrm{K}^{-1}$

Gravitational acceleration, $\mathrm{m} . \mathrm{s}^{-2}$

Thermal conductivity, W. $\mathrm{m}^{-1} \cdot \mathrm{K}^{-1}$

$\mathrm{H}, \mathrm{W} / \mathrm{m}^{2} . \mathrm{K}$

Parts per million 
AC MWCNT HEG
Nanoparticle

Nusselt number

Hydrogen

Nitrogen

Silver

Silica

Ferum

Titanium

Oxide

Alumina

Chloride

Copper

Aurum

Distilled water

Sodium Dodecyl Sulfonate

Volume fraction percentage, $\%$

Weight fraction percentage, $\%$

Meter, $\mathrm{m}$

Pressurized water reactors

Critical heat flux

Computational fluid dynamics

Fourier transforminfrared spectroscopy

Thermogravimetric analysis

Transmission electron microscopy

Scanning electron microscopy

Alternating current power supply

Multi walled carbon nanotube

Heavy ethylene glycol

\section{APPENDIX}

1. Figure 1. Growth of publications on nanofluids

2. $\quad$ Figure 2. Published papers mentioned

3. Figure 3. Stable(right) \& unstable(left) nanofluids

4. $\quad$ Figure 4. Experimental set up for $\mathrm{Al}_{2} \mathrm{O}_{3}$ nanofluid

5. $\quad$ Figure 5. Experimental set up for $\mathrm{Fe}_{3} \mathrm{O}_{4}$ nanofluid

6. Figure 6. Experimental set up for $\mathrm{Fe}_{3} \mathrm{O}_{4}$ nanofluid

7. $\quad$ Figure 7. Experimental set up for $\mathrm{Fe}_{3} \mathrm{O}_{4}$ nanofluid

8. Figure 8. Experimental set up for $\mathrm{CuO}$ nanofluid

9. Figure 9. Experimental set up for Ag nanofluid

10. Figure 10. Experimental set up for $\mathrm{Al}_{2} \mathrm{O}_{3}$

11. Figure 11. Experimental set up for ethylene glycolbased $\mathrm{Al}_{2} \mathrm{O}_{3}$

12. Figure 12. Experimental set up for graphene nanofluid

13. Figure 13. Experimental set up for $\mathrm{SiO}_{2}-\mathrm{CuO}$ nanofluid

14. Figure 14. Experimental set up for $\mathrm{Ag} \& \mathrm{Cu}$ in tubular heat exchanger

15. Figure 15. Experimental set up for $\mathrm{CNT}-\mathrm{TIO}_{2}$

16. Table 1. Table of constant, manipulative, and responding variables

17. Table 2. Summary of thermal conductivity enhancement of nanofluids

18. Table 3. Research on decorated graphene nanofluids

19. Table 4. Experimental design outcomes summary 